\title{
t......
}

\author{
高強度場の科学：基礎と展望 \\ 加藤 義章 \\ 日本原子力研究所関西研究所 光量子科学研究センター（テ619-0215 京都府相楽郡木津町梅美台8-1)
}

\section{Prospects of High-Field Science}

\author{
Yoshiaki KATO \\ Advanced Photon Research Center, Kansai Research Establishment, Japan Atomic Energy Research Institute \\ 8-1 Umemidai, Kizu, Souraku, Kyoto 619-0215
}

(Received March 13, 2001)

\begin{abstract}
Electrons as well as ions are accelerated to high energy by extremely high pressure generated with intense optical field at the focus of ultrashort pulse high power lasers. Even relativistic ions could be generated at the intensity close to $10^{25} \mathrm{~W} / \mathrm{cm}^{2}$. Development of ultra-compact accelerators and high brightness $\mathrm{x}$-ray sources with T-cube lasers (table-top TW lasers) at the Advanced Photon Research Center are described.
\end{abstract}

Key Words: Ultrashort pulse laser, X-ray laser, High field science, Relativistic nonlinear optics, Particle acceleration

1. はじめに

チャープパルス増幅 ${ }^{1)}$ (Chirped Pulse Amplification: CPA) は, 光科学に極めて大きな変革をもたらした2). 高エネル ギーレーザー光の生成には向いているが, 超短パルスレー ザー光の直接増幅は困難な $\mathrm{Nd}$ ガラスレーザーを用い, 高エ ネルギーで且つ高ピーク出力の超短パルスレーザー光の 生成が可能になった。これが契機となって, 高密度プラズ マの高速点火 ${ }^{3)}$ という新しい概念が生み出され，レーザー 核融合に新たな展開がもたらされた。また,短パルスレー ザー励起により電子衝突励起X線レーザーの効率が向上す

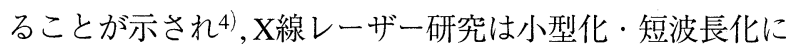
向けて新たな展開を遂げることとなった。

さらに, チタンサファイアレーザーに代表される広帯域 のレーザー結晶を用い, 繰返し動作が可能な小型の高出力 極短パルスレーザー (Table-Top TW Laser：Tキューブレー ザー)が実現された。CPAチタンサファイアレーザーの登 場により, 極短パルスレーザーが使い易い装置となり, 高 次高調波光の生成や, 超高速光化学など, 超高速科学研究 に急速な進歩をもたらした。また, 実験室規模の装置で超 高強度場の生成が可能になり, MeV以上の高エネルギー域 を対象とする研究が, 小型レーザー装置で実施できるよう になってきた.

Tキューブレーザーでもたらされる新しい科学技術に関 する先駆的な調査研究が1995年に科学技術庁で実施され5), その研究実施機関として, 日本原子力研究所に関西研究所 光量子科学研究センターが1996年に設置された. 同研究
センターは, 原研の東海研究所, 寝屋川事業所等の既設建 物を利用して研究の立ち上げを行ってきたが, 1999年6月に 関西学術研究都市の木津南地区に新しい研究施設が完成 し,ここを拠点として本格的な研究を構築しつつある.

本稿では, 超高強度場の生成と物質との相互作用につい て概観し, 次いで光量子科学研究センターの研究概要を紹 介する。

\section{2. 超高強度場の生成}

リバモア研でNd:ガラスレーザーにより1PW出力が実現 され, 集光強度 $10^{20} \mathrm{~W} / \mathrm{cm}^{2}$ を超える強度での実験が行われ た6).このレーザーは既に解体されているが, 阪大, ラザ フォード研等で1PW級レーザーの稼働が予定されてい る. 他方, チタンサファイアレーザーの高出力化も進めら れており, 100TW級レーザーが原研, LOA (仏), ミシガン大 (米)等で稼働を開始し, 原研では1PW級へのアップグレー ドも予定されている. CPAガラスレーザーとCPAチタンサ ファイアレーザーのパルス幅はそれぞれ約500fs, 30fsであ り, 同じ1PWでもエネルギーは $500 \mathrm{~J}, 30 \mathrm{~J}$ と大きく異なる. パルス幅, エネルギーにより流体としての応答が異るので, 同じ集光強度でも起こる現象は必ずしも同じではないが, これらのレーザーを用いた高強度科学がさらに大きく発 展すると予測される。

現在の技術でどの程度まで高出力化が可能かを試算す る. CPAで高ピーク出カレーザー光を生成する場合を考え よう。レーザー媒質から引き出せるエネルギーは, 飽和フ 
ルエンス $F_{\mathrm{sat}}=h v / \sigma(\sigma$ は誘導放出断面積 $)$ が光学素子の損 傷フルエンス $F_{\mathrm{d}}$ より小さい場合は $F_{\mathrm{sat}}$ で与えられる。レー ザー媒質の帯域を $\Delta v$ とすると最小パルス幅は $\tau=1 / \pi \Delta v$ と なるので, $F_{\mathrm{sat}}<F_{\mathrm{d}}$ の場合, 単位面積当たりの最大ピーク出 力は $P_{\max }=(h v / \sigma) \pi \Delta v$ となる. この出力光を回折限界 $\left(F \lambda^{2}\right.$, $F$ は集光系のF值)にまで集光すると, $I_{\max }=(\pi / F)\left(h v^{3} \Delta v /\right.$ $\left.\sigma c^{2}\right)$ の集光強度が得られる.

多くの光学素子の損傷耐力 $F_{\mathrm{d}}=5-10 \mathrm{~J} / \mathrm{cm}^{2}$ に対し, チタン サファイアレーザーは $F_{\text {sat }}=1 \mathrm{~J} / \mathrm{cm}^{2}$ であるので, 飽和増幅に より効率良くエネルギーを取り出すことができる。レー ザー波長 $\lambda=800 \mathrm{~nm}$, 帯域幅 $\Delta \lambda=40 \mathrm{~nm}$ より, パルス幅は $\tau=$ $16 \mathrm{fs}$ となる。これより,ピーク出力はレーザー媒質 $1 \mathrm{~cm}^{2}$ 当た り $P_{\max }=60 \mathrm{TW}, F / 3$ で集光すると集光強度は $I_{\max }=3 \times 10^{21} \mathrm{~W} /$ $\mathrm{cm}^{2}$ となる. 高繰返し動作が可能な $1 \mathrm{TW}$ 級チタンサファイ アレーザーでも, $10^{19} \mathrm{~W} / \mathrm{cm}^{2}$ 超える高強度場の生成が可能 である。

$1 \mathrm{PW}$ 超える高出力レーザー光も, $20 \mathrm{~cm}^{2}$ 程度のチタン サファイア結晶により実現することができる，さらに結 晶を2次元配列し面積を $2,000 \mathrm{~cm}^{2}$ (ビーム径 $\left.25 \mathrm{~cm}\right)$ とすれば, ピーク出力が $\mathrm{EW}\left(10^{18} \mathrm{~W}\right)$ で強度が $10^{24-25} \mathrm{~W} / \mathrm{cm}^{2}$ の, 超高強 度場の生成も可能となる。（実際にはレーザー光の強度分 布が均一でないので, 上記の 1.5 倍程度の面積が必要にな る. )

また, LD直接励起が可能 (したがって高効率) で, かつ飽 和フルエンスの高いYb:YLF $\left(\lambda=1100 \mathrm{~nm}, \Delta \lambda=40 \mathrm{~nm}, F_{\mathrm{sat}}=\right.$ $\left.5 \mathrm{~J} / \mathrm{cm}^{2}\right)$, あるいはYb:ガラス $\left(\lambda=1100 \mathrm{~nm}, \Delta \lambda=40 \mathrm{~nm}, F_{\mathrm{sat}}=\right.$ $\left.20 \mathrm{~J} / \mathrm{cm}^{2}\right)$ を増幅媒質として用いると, 超短パルスレーザー を大幅に小型化・高出力化でき $10^{25} \mathrm{~W} / \mathrm{cm}^{2}$ 超える場を生 成できる可能性がある.

レーザーの大型化, 高平均出力化で問題となるレーザー 媒質内での寄生発振や発熱の影響を受けない方法として, 非線形光学結晶をレーザー媒質の代りに用いるパラメト リックチャープパルス増幅7) (Optical Parametric CPA: OPCPA)が, 最近提案されている. 非常に増幅率が大きい ので, 励起レーザー光強度分布の空間的な均一性が重要に なるなど, 従来法とは異なる課題が生まれるが, 技術が確 立している固体パルスレーザーをそのまま使用できる利 点もあり, 新しい高出力超短パルスレーザー光生成法とし て注目される。これらより,現在のCPAレーザーの延長, あ るいは新しいレーザー媒質の開発により EW程度までの高 出力化は可能で, OPCPAによりEW以上も実現できるかも しれない.

\section{3. 高強度場と電子の相互作用}

高出カレーザー光を集光することにより, 小さな空間に 極めて強い場を生成し, 非常に高い圧力を物質に与えるこ とができる. 真空中では, 光強度 $I$ は電界の振幅 $E_{0} に よ り I$ $=E_{0}^{2} / 2 Z_{0}\left(Z_{0}=337 \Omega\right.$ は真空のインピーダンス $)$ と表される. 即ち $E_{0}(\mathrm{~V} / \mathrm{m})=27\left[I\left(\mathrm{~W} / \mathrm{m}^{2}\right)\right]^{1 / 2}$ と表され, 強度 $10^{20} \mathrm{~W} / \mathrm{cm}^{2}$ に おいて $E_{0}=27 \mathrm{TV} / \mathrm{m}$ となる. この時, 光の圧力 $P=I / c$ は 30Gbarにも達する。 このような高強度場と物質との相互 作用について考える.
電子 (電荷 $e$, 静止質量 $m$, 速度 $v)$ は電磁場により

$$
\boldsymbol{F}=e[\boldsymbol{E}+(\boldsymbol{v} / c) \times \boldsymbol{B}]
$$

の力を受け, 運動方程式は $m d v / d t=\boldsymbol{F}$ となる. 光強度が小 さくv/cが1より小さい場合, 右辺第2項は第1項に比べて小 さい. 電界の振幅を $E_{0}$ とすると, 第一近似の運動方程式 $m d \boldsymbol{v} / d t=e \boldsymbol{E}$ より, 電子の振動速度の最大值は $v_{0}=e E_{0} / m \omega$ と なる. 光電界の強さとして $a_{0}=e E_{0} / m c \omega$ と定義すると, $a_{0} \ll$ 1 (即ち $\left.v_{0}<<c\right)$ の場合はこのような非相対論的扱いができ る. $a_{0}$ はレーザー光の波長 $\lambda(\mu \mathrm{m})$ と強度 $I\left(10^{18} \mathrm{~W} / \mathrm{cm}^{2}\right)$ を用 いて

$$
a_{0}=0.85 \lambda(\mu \mathrm{m}) I^{1 / 2}\left(10^{18} \mathrm{~W} / \mathrm{cm}^{2}\right)
$$

と表され, $\lambda=0.8 \mu \mathrm{m}$ の場合, 強度 $I=2 \times 10^{18} \mathrm{~W} / \mathrm{cm}^{2}$ において $a_{0}=1$ となる。

光強度が空間分布を持つ場合を考え,電子の速度を電場 $\boldsymbol{E}$ による振動成分 $\boldsymbol{v}_{\mathrm{osc}}$ と, その他の摂動項 (右辺第2項の寄与 を含む) $\delta v$ の和として $\boldsymbol{v}=\boldsymbol{v}_{\mathrm{osc}}+\delta \boldsymbol{v}$ と書くと, $\delta \boldsymbol{v}$ の運動方程 式は, 直線偏光の場合,

$$
m \partial \delta \boldsymbol{v} / \partial t=-m c^{2} \nabla\left(a_{0}^{2} / 4\right)=-\nabla U_{\mathrm{p}}
$$

となる ${ }^{8)}$. 即ち, 電子に対して光強度の勾配に比例した质 力(動重力)が働く.ここで,

$$
U_{\mathrm{p}}=e^{2} E_{0}^{2} / 4 m \omega^{2}
$$

は動重力ポテンシャルと呼ばれ, 電子の振動エネルギーの 時間平均 $m<v^{2}>/ 2$ に相当する。 $U_{\mathrm{p}}$ の大きさは, $U_{\mathrm{p}}(\mathrm{keV})=$ $0.94 \times 10^{2} I\left(10^{18} \mathrm{~W} / \mathrm{cm}^{2}\right) \lambda^{2}(\mu \mathrm{m})$ となり, $I=10^{18} \mathrm{~W} / \mathrm{cm}^{2}$ にお いて,電子は約100keVの振動エネルギーを持つ.

高強度の超短パルスレーザー光がプラズマ中を伝搬す ると, 動重力により電子が押し出され, 電子密度 $\left(n_{0}\right)$ が低下 する. プラズマ振動数

$$
\omega_{\mathrm{p}}=\left(4 \pi n_{0} e^{2} / m\right)^{1 / 2}
$$

を用い, プラズマの屈折率は $n=\left(1-\omega_{\mathrm{p}}{ }^{2} / \omega^{2}\right)^{1 / 2 て ゙ 与 え ら れ ~}$ る.これより,レーザー光は $\omega>\omega_{\mathrm{p}}$ の低密度域で伝搬でき るが, 屈折率が1(真空の屈折率)より小さいので, 密度が低 下すると屈折率は大きくなる。レーザー光の半径方向の 強度分布を考えると, 光軸付近の電子密度が低下し, 屈折 率が大きくなるため,レーザー光は自己収束する(動重力自 己収束効果).

また, 超短パルスレーザー光の進行方向の強度分布によ る動重力により,プラズマ中に粗密波が形成され, 縦方向 に非常に強い電界が生成される。この粗密波はレーザー 光の伝搬に伴って進行する航跡波となる。航跡場は約 $100 \mathrm{GeV} / \mathrm{m}$ とマイクロ波空洞共振器の 1000 倍程度大きな值 となるので, 電子を航跡場の加速相に乗せることにより, 短 距離で高エネルギーに加速することが可能になる9).

光強度が強くなり, $v \sim c$, 即ち $a_{0} \sim 1$ になると, 相対論的効 果が顕著となってくる. 例えば, 電子の振動エネルギー $U_{\mathrm{p}}$

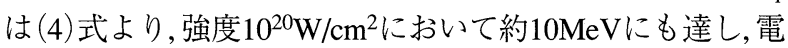
子の静止質量 $(511 \mathrm{keV})$ を大きく超える. 高エネルギー電 子が原子あるいはイオンと相互作用するとき, 制動放射に 
よる連続スペクトルX線, あるいは内殼電子の電離による 特性X線などが生成される。

また, 電子の質量が大きくなり $\left(m \rightarrow \gamma m, \gamma=\left(1-v^{2} / c^{2}\right)^{-1 / 2}\right)$, (5)式のプラズマ振動数が低下する. その結果, 屈折率が大 きくなり,レーザー光が自己収束し(相対論的自己収束効 果), 入射強度よりもさらに高い強度となる。 また, $\omega<\omega_{\mathrm{p}}$ とレーザー光が進入できない高密度プラズマでも, プラズ マ振動数が低下する結果 $\omega>\omega_{\mathrm{p}}$ となり,レーザー光が伝搬 できるようになると予測される。

強度が高くなると, 光の圧力により電子はz方向に加速さ れる. 即ち, $a_{0}$ が 1 程度になると, (1) 式右辺の第 2 項が第 1 項 と同程度の大きさになるが,この項は電界の位相によらず 常に $+z$ 方向の力を与える. 第 1 項は電子に対し $x$ 方向の上 下振動を与えるが, 第2項の効果 $(z$ 方向の力)により, 電子の 軌跡は8の字型となる. 即ち電子は非線形振動となり, 高調 波光が生成される(非線形トムソン散乱と呼ばれる).さら に $a_{0} \gg 1$ になと, 電子の縦方向の運動量が横方向の運動量 より遙かに大きくなり $\left(P_{z} \gg P_{x}\right)$, 電子はFig.1のように殆ど 前方に進むようになる。電子は非常に強い加速度を受け るため, 前方に小さな広がり角で連続スペクトルの短波長 光を放出する。この放射はラーマー放射とも呼ばれ, $z$ 軸か ら $\theta=2 / a_{0}$ の角度にピークをもち, 中心エネルギーは $a_{0}=10$ $\left(I \sim 10^{22} \mathrm{~W} / \mathrm{cm}^{2}\right)$ で $h v=400 \mathrm{eV}$ となる ${ }^{10)}$. ラーマー放射の強 度は電子密度に比例し, 高密度では強い放射が得られると

a $<<1$

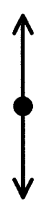

Fig.1 Trajectories of an electron under optical field at weak intensity $(a<<1)$, relativistic intensity $(a \sim 1)$, and extremely high intensity $(a>>1)$.
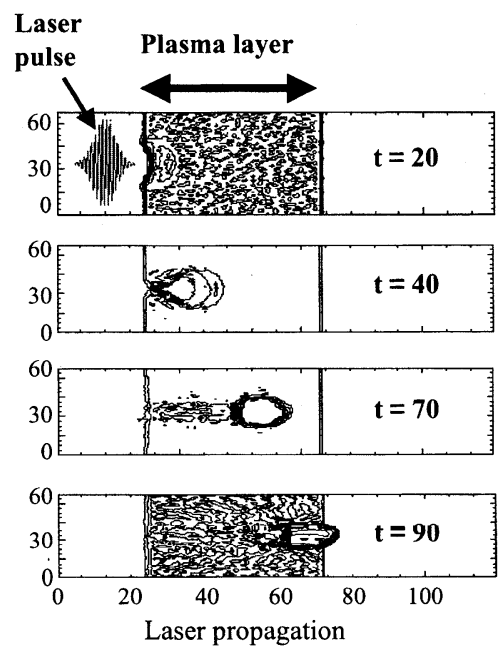

予測されるが, 高強度場による電子密度の低下等を含めた 評価が必要である。なお, 加速される電子にレーザー光を 衝突させて,逆コンプトン散乱で強いX線を生成する方法 も提案されている10).

高強度レーザー光を固体薄膜に照射すると, 光圧力によ り電子が高エネルギーに加速され, 薄膜後面に高フラック スの電子流として放出される．先行して放出される電子 流(電荷分離)により生じる非常に強い電界, 電子が飛び出 した後の非中性プラズマのクーロン爆発, プラズマ中に生 じる超強磁場の時間変化に伴う電流等により,イオンが高 エネルギーに加速される． $20 \mu \mathrm{m}$ と厚い高密度プラズマ $\left(10^{20} \mathrm{~cm}^{-3}\right)$ を $10^{21} \mathrm{~W} / \mathrm{cm}^{2}$ で照射したとき,レーザー光は裏面 まで貫通し, ターゲット後面に約 $5 \mathrm{MeV}$ のイオンが生成さ れると予測される11) (Fig.2). 照射条件を最適化すると, $10^{21-22} \mathrm{~W} / \mathrm{cm}^{2}$ の強度で,イオンを相対論的なエネルギーにま で加速できるとのシミュレーションも発表されている12). 最近の実験で430MeVの高エネルギーイオンの生成が観測 されている13).

このように, 高強度レーザー光によりイオンをパルス的 に相対論的エネルギーに加速できる可能性が生まれてき ており,小型大強度イオン源によるニュートリノ生成など, レーザーを用いた高エネルギー物理学が拓かれようとし ている14).

レーザー光と物質との相互作用は, レーザー光のパルス 幅によっても大きく変化する．レーザー光は先ず電子と 相互作用し, 次いで電子系から格子振動など他の自由度へ とエネルギーが伝えられる。レーザー光のパルス幅(レー ザーと電子との相互作用時間) と他の自由度への緩和時間 (位相緩和, エネルギー緩和) とその特性時間 (固有振動数) との関係により,現象の現れ方が大きく異なってくる，パ ルス幅が長いと,電子系から他の自由度へとエネルギーが 移行しつつ加熱が継続し, 非常に多くの系が励起される. しかしパルス幅が短いと, 殆ど純粋に電子系のみが励起さ れ, 次いで緩和時間が短い限られた系のみが励起される。 このため, 電子系を効率よく高いエネルギー状態に励起し,
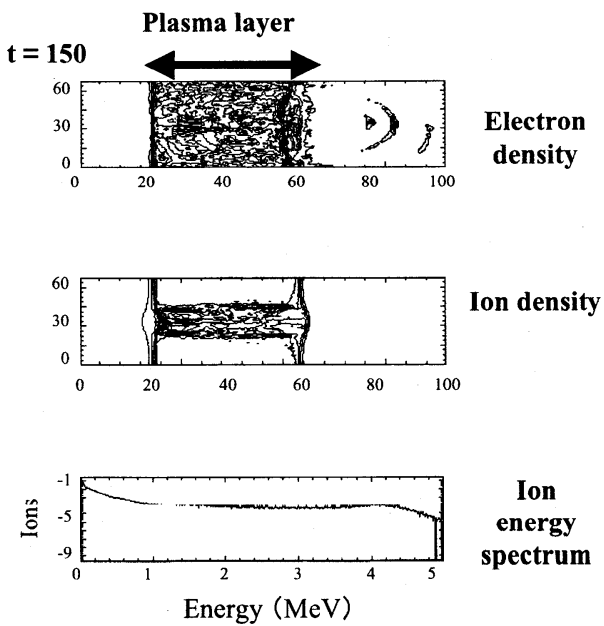

Fig.2 Propagation of an intense laser pulse through a high density plasma. ${ }^{11)}$ Target thickness is approximately $20 \mu \mathrm{m}$ and the laser intensity is $10^{21} \mathrm{~W} / \mathrm{cm}^{2}$. Left figures: electron density contours during the laser propagation. Right figures: density contours of electrons (top) and ions (middle) and the ion energy spectrum (bottom), after the laser pulse has passed through the plasma. Spatial scale is in unit of laser wavelength and the time scale in laser frequency $\omega$. 
且つ制御しつつ特定の他の系を励起することが可能にな る。

物質は, 原子・分子, 凝縮系, プラズマ, 原子核, 素粒子等 多様であり，個々の系に多くの自由度が存在する。T キューブレーザーは,これらの物質系の素過程を解明し, 制 御する新しい手段を提供する。

\section{4. 光量子科学研究センターにおける研究}

光量子科学研究センターでは, 高性能のTキューブレー ザーを開発し, それを用いて加速器及びX線レーザーの小 型化を実現することを目標として, 研究を行ってきた。発 足以来の研究成果は年報15)をご覧いただくこととし，ここ では最近の研究状況を紹介する。

\section{1 実験施設}

3 節で述べたように集光強度が約 $10^{19} \mathrm{~W} / \mathrm{cm}^{2}$ を超えると, $1 \mathrm{MeV}$ 以上のエネルギーの電子が生成され，これに伴い高 エネルギーX線が発生する。発生X線量はターゲット(気 体, 固体, 原子番号等) で異なるが, 特に繰り返し動作高出 カレーザーを用いた実験装置は, X線発生装置としての取 り扱いが必要となる。このため光量子科学研究センター では, 高強度実験室を他の部屋と分離し, 入室制限下で実 験を行うよう実験棟が設計されている。

実験棟の配置図をFig.3に示す．図に示されている4大実 験室は各 $15 \mathrm{~m} \times 30 \mathrm{~m}$ の大きさで, それぞれ独立に, あるいは 結合して使用する。図左下の高出力レーザー実験室はク リーンルーム仕様で, 埃, 温度, 湿度, 振動等をコントロー ルし, 高出力レーザー光を安定に生成する。ここで生成さ れた100TWレーザー光を, ビームラインを通して右上の レーザー加速実験室に導く、レーザー加速実験室は壁厚 $1 \mathrm{~m}$ のコンクリート壁を有し, レーザー加速, 高強度光科学 など, 硬X線生成を伴う実験を実施できる，右下の高繰り 返しレーザー実験室では, LD励起Nd:YAGレーザーを励起 源とするチタンサファイアレーザーなど, 小型超短パルス レーザーの開発と利用の研究を行う。また, 左上のX線 レーザー実験室では, CPA Nd:ガラスレーザーにより小型 X線レーザーの開発を行っている。これら4大実験室の周 囲に配置された小実験室において,小型レーザーを用いた独 立した実験や, 光学素子開発などの研究を実施している.

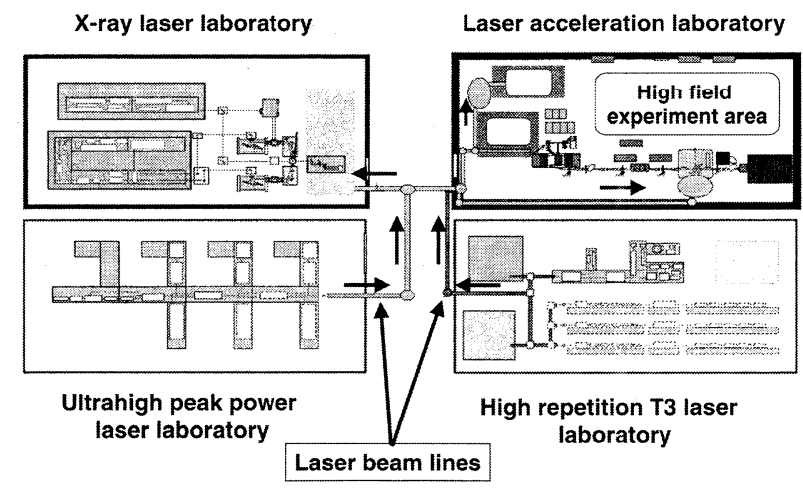

Fig.3 Layout of the laboratory building at the Advanced Photon Research Center.
1)高出力チタンサファイアレーザーの開発

各種の利用研究を実施するには, 安定に動作するレー ザーが必要であり,高出力超短パルスレーザーにおいては, システム全体にわたり細かい配慮が必要となる。光量子 科学研究センターでは, 1PW級チタンサファイアレーザー の開発を1996年から開始し, 10TW, 100TW出力を'97, '98年 に実現した ${ }^{16)}$.1999年に木津の新施設に移転後, 100TW レーザーを再構築すると共に, 1PW化への準備を行ってい る.

100TWシステムは, 発振器, パルス幅拡張器, 再生増幅器, 前置増幅器, 主増幅器, パルス圧縮器で構成され, 繰り返し $10 \mathrm{~Hz}$, パルス幅 $19 \mathrm{fs}$, エネルギー $1.9 \mathrm{~J} /$ パルス, ピーク出力 100TWで動作する。短いパルス幅を得るために, 再生増幅 器内での高帯域増幅や, 高带域位相制御を可能とするパル ス幅拡張器・圧縮器の設計などが工夫されている.

最終増幅器には, 直径 $40 \mathrm{~mm}$, 長さ $25 \mathrm{~mm}$ のチタンサファ イア結晶(水冷)を用い,これを $10 \mathrm{~Hz}, 7 \mathrm{~J} /$ パルスの $532 \mathrm{~nm} \mathrm{Nd:}$ YAGレーザーで励起している. チタンサファイアレー ザーの高出力化における困難さの一つは, 励起レーザーの 高出力安定動作にある。我々は新しく開発した高調波発 生法により 70\%以上の第2高調波変換効率を得ることに成 功し17), この方法を励起レーザーに組み入れつつあり, こ れにより安定領域での高出力動作が可能になる.

100TWレーザーの出力変動は数\%以内であり, 自動光軸 安定装置の導入により約 $5 \mu \mathrm{rad}$ 以内で光軸が安定してい る. 出力光の波面収差 ${ }^{18)}$ は約 $\lambda / 20(\mathrm{rms})$ で, 回折限界に近い 集光径が得られている。自然放射光増幅に起因する背景 光の值 (3次相関計で測定) は, ピーク值の $10^{-6}$ 程度でかなり 良い值であるが,イオン化しやすいターゲットを用いる実 験では改善が必要になるかもしれない.

加速実験室での本格的な実験に先立って, 最近10TW出 力での実験を開始した。レーザー光電界によるアルゴン 原子のイオン化実験を行い, $\mathrm{Ar}^{16+}$ (2s 電子まで電離)の生成 を示すデー夕を得た．各イオン種の生成率の強度依存性 は, 個々の電子の段階的イオン化を記述するADK理論 ${ }^{19)}$ (Ammosov-Delone-Krainov) と異なる様子20)を示しており， 電子相関に関する新しい知見を提供するかもしれない. レーザー強度は $1 \times 10^{19} \mathrm{~W} / \mathrm{cm}^{2}$ に達しており,このような相 対論域での光電離の実験と理論は発表されていない. 原 子物理学的興味に加え, 光電離により生成する多価イオン は,イオン源としての用途もあるものと思われる.

100TWレーザーに更に増幅器を追加することにより， 1PW化を尖現できる。自径 $8 \mathrm{~cm}$ の)タンサファイア結晶, 励起レーザー(150J Ndガラスレーザー), パルス圧縮器など の準備を終え, 2001年から実験を開始する予定である。

2)電子加速と高エネルギーイオン生成

超短パルス高強度レーザー光は,その非常に強い光電場 により超小型の加速器となる. 光量子科学研究センター では, 航跡波電子加速と高エネルギーイオン生成を計画し ている。

航跡波電子加速に関しては, 第1段階の加速実験を, 東大 原子力工学研究施設, 高エネルギー物理学研究所との共同 
研究として 1998 年迄に実施し, $17 \mathrm{MeV}$ の入射電子を $2 \mathrm{TW}$ レーザーにより加速し, 最高 $300 \mathrm{MeV}$ の高エネルギー電子 の生成に成功した ${ }^{21)}$ 。この時観測された電子のスペクト ルは連続的であり，一部の入射電子のみが位相整合して加 速されたものと推定される。制御して電子を加速するに は, 入射電子パルスを航跡波の波長 $($ 数 $100 \mu \mathrm{m})$ 上り短くし， 大部分の電子を加速位相に乗せることが必要である。

現在準備を進めている第2段階の実験配置をFig.4に示 す。マイクロトロンで生成した低エミッタンス電子を, 周 期磁場中でレーザー光と相互作用させてエネルギー変調 を与え, 変調された電子パルスのみを取り出す。電子加速 用のレーザー光の一部を電子切り出しに使用することに より，同期を正確にとることが可能になる。超短パルス レーザー光により低密度プラズマ中に航跡波を生成し,こ の電子パルスを加速する. 回折限界よりも長い距離にわ たって光と電子を相互作用させるため, プラズマ導波路を 使用する。この実験により, 数 $\mathrm{cm}$ の距離で電子を $1 \mathrm{GeV}$ 以 上に加速し, エネルギー広がりの少ない加速電子が生成さ れると期待される。

マイクロトロンは,据え付け・調整を経て2000年より稼 働を開始した，光電子陰極で生成した電子をマイクロト ロンで加速し, エネルギー $150 \mathrm{MeV}$, パルス幅 $100 \mathrm{ps}$, 電荷 $100 \mathrm{pC}$ ，エミッタンス $6 \pi \mathrm{mm} \operatorname{mrad} の$ 電子ビームを得てい る。また, 高速Zピンチ細管放電によるプラズマ導波路の 開発を並行して進めた.プラズマ導波路では,管軸上の電 子密度が管壁部より低く，したがって屈折率が中心部で高 くなっており,レーザー光と電子ビームは共に中心部をガ イドされる，細管放電中の超短パルスレーザー光の伝搬 を観測し，長さ $2 \mathrm{~cm}$ にたって $64 \%$ の透過率でレーザー光 を導波できることが示された22). 他の機器を設置し, Fig.4 に示す実験を2001年に実施する予定である。

100TWレーザーにより,高エネルギーイオンの生成と利 用に関する研究が可能になる。3節で述べたように, $10^{20}$ $\mathrm{W} / \mathrm{cm}^{2}$ を超える強度で薄膜を照射すると, 数 $10 \mathrm{MeV}$ の高工 ネルギーイオンがターゲット裏面に小さな角度で放出さ れる。レーザー光からイオンへのエネルギー変換効率は $10 \%$ 以上で, 強度が上がるほど放出角度が小さくなり, 変換 効率も向上する.

高エネルギーイオンの生成は, 超高強度場で発生する諸

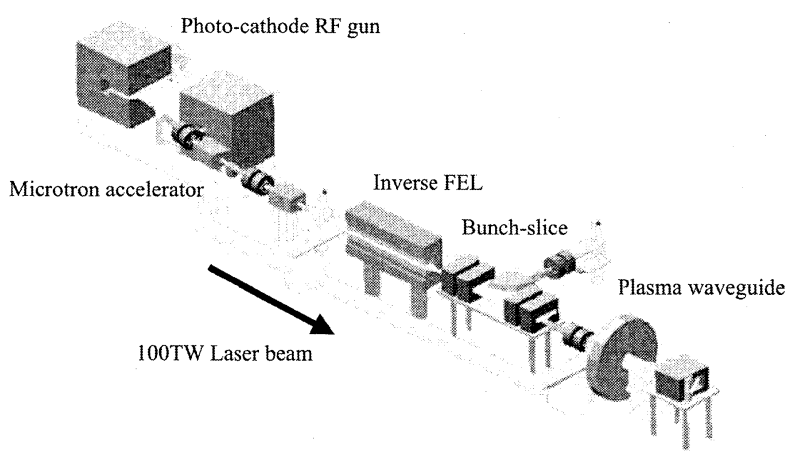

Fig.4 Layout of the wake-field electron acceleration experiment. Short-pulse electrons generated with the inverse FEL and bunch-slicing are accelerated with the $100 \mathrm{TW}$ laser pulse in the plasma waveguide.
現象の一端であり,この解明と利用は高強度場科学にとっ て, 重要な課題である. また, 高エネルギー粒子加速器は, 工学, 医療等の分野で多くの利用されており, その小型化 は加速器ビームの普及に大きな役割を果たすと期待され る23).

\section{3) 超短パルスX線の発生と応用}

超短パルスレーザーにより, 高輝度の超短パルスX線を 生成することができる。この方法は, 生成X線のパルス幅 が短いこと,及び小型レーザーにより硬X線を生成できる との特徵を有する。硬X線源の小型化により,今まで大型 放射光により開発されてきたX線利用技術を, 実用化へと 結びつけることができると産業界から期待されている。

生成X線の短パルス性を生かし, 数 $\mathrm{keV}$ の特性X線 $(\mathrm{K}-\alpha$ 線)を用いたブラッグ回折実験が行われ，レーザー加熱によ る結晶の構造変化(膨張, 音波の伝搬, 溶解など) が時間分 解で直接調べられるようになった ${ }^{24)}$ 。また, より高強度で 生成される数 $10 \mathrm{keV}$ の硬X線を用い, 血管造影による心臓診 断への使用も検討されている.

これらの研究で原理実証は行われたが, 実用化にはX線 源の高輝度化とX線利用効率の改善が必要である、今まで のこれらの実験では, 1TW級レーザーが主として使われて きた.これは数 $\mathrm{keV}$ 特性X線の生成には $10^{17} \mathrm{~W} / \mathrm{cm}^{2}$ 程度の照 射強度が最適であること, 及び10TW級高出力レーザーは 安定動作, 及びマシンタイムの確保の面で「使いにくい」こ とが起因している。しかし, 1TW級レーザーでX線回折の データをとるには,数100ショットのデー夕蓄積が必要とさ れる。したがって測定対象は, X線回折効率の高い物質で, 且つ再現性の良い現象に限られる。

今後, 蛋白質等の低Z物質を対象とし,これらの構造の時 間変化を測定することが益々重要になってくると予測さ れる。このためには現在の技術を大幅に改良することが 必要である。レーザーの高出力化は, 必ずしもX線輝度の 向上につながるわけではないが, 照射条件の最適化, X線 光学系の開発などにより,レーザー生成X線源の利用範囲 を広げる可能性を秘めている。そのために, 超高出力レー ザーを用いたX線源の開発に関する基礎研究を実施する予 定である。

4) X線レーザーの研究

オングストローム域のX線レーザーは,上記の目的に最 適な光源である，輝度が高く, パルス幅が短いので, 単一 ショットで過渡現象を記録できる。さらに,コヒーレント X線であるので,X線回折の構造決定で問題となる位相問題 が無くなり,蛋白質等の複雑な構造の分子でもX線ホログ ラフィーにより決定できるようになる。

このような短波長域でのX線レーザーを実現する方法と して, 内款電子を電離し, 外殼電子との間に反転分布を生 成する方法が考えられる。内殼電離状態の寿命は極めて 短いので, 反転分布を生成するには, 小さな時間・空間域 にエネルギーを集中し, 選択的に内殼を電離することが必 要となる. Rhodes等は, キセノンクラスターを短波長・超 短パルスレーザー光で照射し, 内殼電離に起因する $2.8 \AA \mathrm{X}$ 
線が効率よく発生することを見いだしている25). 誘導放 出が起きている証拠は明確でないが, オングストローム域 X線レーザーへの手がかりを与えるものとして注目され る.

各種X線源の光子数(パルス当たり)とパルス幅を,軟X線 源 $(\lambda>1 \mathrm{~nm})$ と硬X線源 $(\lambda<1 \mathrm{~nm})$ を分けてFig. 5 に比較す る. 光子数は全立体角に放出される量であり,レーザープ ラズマK- $\alpha$ 線の試料上の值は, 2 桁程度小さくなる. 放射光 はMHz以上の繰り返しで得られるので, 時間平均の光子数 は繰り返しが $1 \mathrm{kHz}$ 以下のレーザー生成X線に比べて, 大き くなる.しかし単一ショットで現象を観測するには, 試料 の反射 (透過) 率 (約 $1 \%$ ), 光学系の透過率・検出器の感度 (約 $1 \%)$, 各画素 $(500 \times 500$ 画素)当たりの光子数(平均 100 個)等を考えると, $10^{11}$ 光子程度は必要となる. 電子衝突励

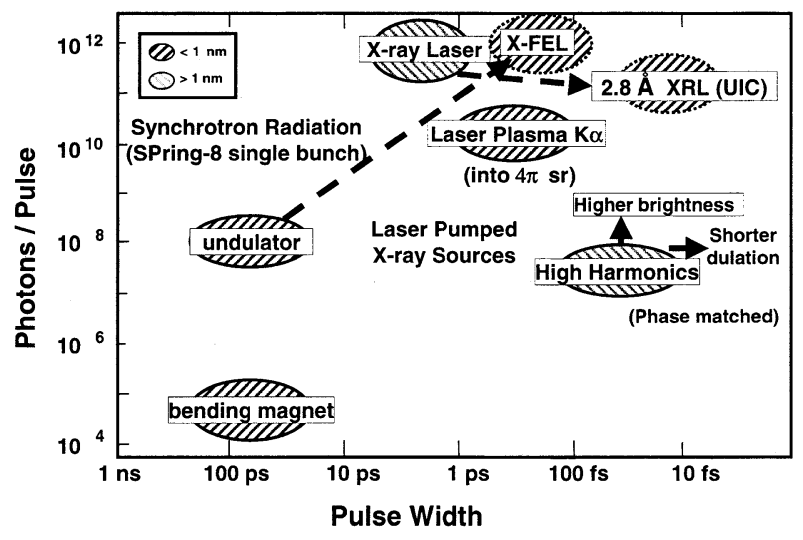

Fig.5 Comparison of photon fluxes of various laser-based $\mathrm{x}$-ray sources, together with the synchrotron radiation sources. Horizontal axis is the pulse width of the $x$-ray source. Soft $x$-ray $(\lambda>1 \mathrm{~nm})$ and hard $x$ ray $(\lambda<1 \mathrm{~nm})$ sources are shown with different shades.
起軟X線レーザーは, この条件を満たしており, X線自由電 子レーザー26)，イリノイ大 $2.8 \AA \mathrm{X}$ 線レーザー25) も同程度の 光子数を持つと予測されている.

我々は, 小型X線レーザーの開発を目標とし, その第1段 階として, 過渡電子衝突励起X線レーザーのコヒーレンス の向上と, 短波長化を進めている。パルス幅 $1 \mathrm{ps,} \mathrm{エネル}$ ギー10JのNd:ガラスレーザー(Fig.6)を励起源とし, 数種の ターゲット物質を使用し, 11.9nm迄の発振に成功した ${ }^{27)}$. 利得の持続時間が数ps程度と短いので進行波励起が必要で あり, 現在準備中の光学系の導入により数 $\mathrm{mm}$ での飽和増 幅が可能になると予測される。発振波長の短波長化には, 励起効率の向上が必要で, プリプラズマ生成法の最適化, 薄 膜ターゲットによる損失の低減等に関する実験を開始し ている.

自然放射光増幅のX線レーザーの時間コヒーレンス長は スペクトル幅 $\lambda / \Delta \lambda \sim 10^{4}$ で決まり, $100 \mu \mathrm{m}$ 程度となる. 今後 の応用を考えると,コヒーレンスの制御が重要である. 波 長と位相が確定したX線レーザー光を生成するために, 波 長可変チタンサファイアレーザーで生成した高次高調波 光をプラズマで増幅する計画で, 利得の持続時間と同程度 の1ps発振器を開発し, 高調波生成実験を行っている. 高精 度に波長が確定した狭帯域X線レーザーを使用できれば, X 線分光学やX線計測に飛躍的な発展がもたらされるであろ j.

\section{5. まとめ}

本報告では, 高強度場の生成と物質との相互作用につい

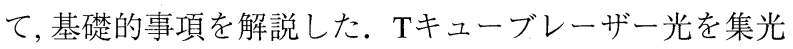
すると極めて強い場が生成され, 電子は高い振動エネル ギーを得る。 $10^{20} \mathrm{~W} / \mathrm{cm}^{2}$ 程度の超高強度場になると, 光圧力 により電子が高エネルギーに加速され, その電子流で生成 される電場により高エネルギーイオンが生成される. 即 ち高強度レーザー光は, 超小型加速器となる. 強度が $10^{25} \mathrm{~W} / \mathrm{cm}^{2}$ 程度になると, 相対論的陽子の生成も可能となる

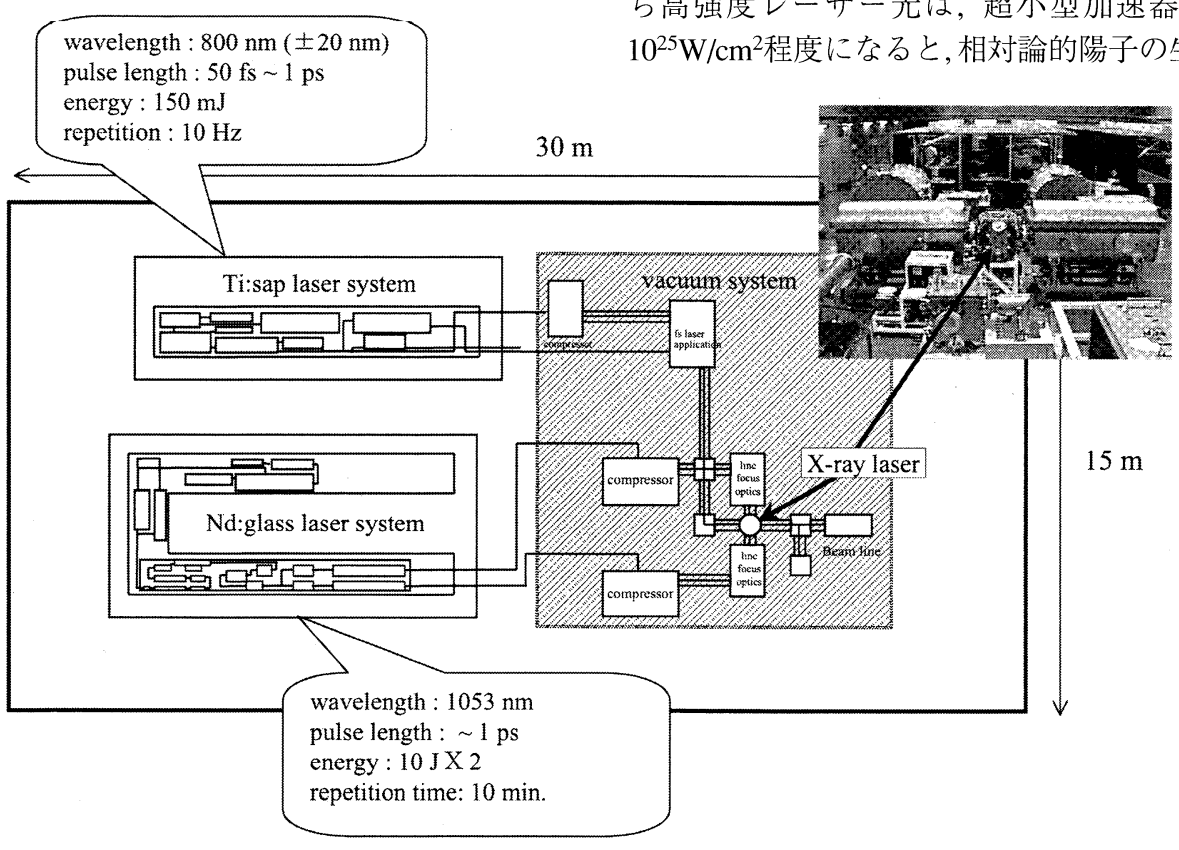

Fig.6 Layout of the x-ray laser experimental system. 
と予測され,レーザー高エネルギー科学へと発展する可能 性もある。

高強度場で駆動された電子のエネルギーは他の自由度 に伝達されるが,それぞれの自由度毎に異なる緩和時間を 有している．超短パルスレーザーでは, 緩和時間の短い自 由度のみを選択的に励起できるので,これらの素過程を解 明し, 制御する新しい手法が拓かれる.

光量子科学研究センターでは, 実用化へつながる可能性 のある課題を対象として, その基礎現象を解明し, 実用化 へ発展させる「応用志向の基礎研究」に重点をおいている。

特に, Tキューブレーザーの開発と応用に関する研究を展 開中で, 本稿ではその一端を紹介した。この分野の研究は 10年以上にわたる歴史があり, 基礎的事項はかなり解明さ れてきた。しかし，高性能Tキューブレーザーが広く使え るようになってきたのは極めて最近であり, 応用へつなが る本格的な研究展開はこれから始まることになろう。

\section{参考文献}

1) D. Strickland and G. Mourou: Opt. Commun. 56 (1985) 219.

2) G. A. Mourou, C. P. J. Barty, and M. D. Perry: Phys. Today Jan. (1998) 22.

3) M. Tabak, J. Hammer, M. E. Glinsky, S. C. Willks, J. Woodworth, E. M. Campbell, M. D. Perry, and R. D. Mason: Phys. Plasmas 1 (1994) 1626.

4) J. Dunn, A. L. Osterheld, R. Shepard, W. E. White, V. N. Shlyaptsev, and R. E. Stewart: Phys. Rev. Lett. 80 (1998) 2825.

5) 光量子の高度利用に関する懇談会 (編) : 光量子科学の誕生と 未来像(科学技術庁原子力局, 1996).

6) S. P. Hatchett, C. G. Brown, T. E. Cowan, E. A. Henry, J. S. Johnson, M. H. Key, J. A. Koch, A. B. Langdon, B. F. Lasinski, R. W. Lee, A. J. Mackinnon, D. M. Pennington, M. D. Perry, T. W. Phillips, M. Roth, T. C. Sangster, M. C. Singh, R. A. Snavely, M. A. Stoyer, S. C. Wilks, and K. Yasuike: Phys. Plasmas 7 (2000) 2076.

7) I. N. Ross, P. Matousek, M. Towrie, A. J. Langley, and J. L. Collier: Opt. Commun. 144 (1997) 125.

8) 杉原 亮, 西田靖, 小方厚 (編著)：超小型加速器(アイピーシー, 1998).
9) T. Tajima and S. M. Dawson: Phys. Rev. Lett. 43 (1979) 267.

10) Y. Ueshima, Y. Kishimoto, A. Sasaki, and T. Tajima: Laser Part. Beams 17 (1999) 49

11) M. Yamagiwa, J. Koga, L. N. Tsintsadze, Y. Ueshima, and Y. Kishimoto: Phys. Rev. E 60 (1999) 5987.

12) T. Zh. Esirkepov, Y. Sentoku, K. Mima, K. Nishihara, F. Califano, F. Pegoraro, N. M. Naumova, S. V. Bulanov, Y. Ueshima, T. V. Liseikina, V. A. Vshikov, and Y. Kato: JETP Lett. 70 (1999) 82.

13) E. L. Clark, K. Krushelnick, M. Zepf, F. N. Beg, M. Tatarakis, A. Machacek, M. I. K. Santala, I. Watts, P. A. Norreys, and A. E. Danger: Phys. Rev. Lett. 85 (2000) 1654.

14) G. Mourou：第2回光量子科学研究シンポジウム招待講演 (日本 原子力研究所関西研究所, 2000年11月, プロシーデイング出版 予定).

15）関西研究所年報 1999 (日本原子力研究所関西研究所, JAERI Review 2001-003).

16) K. Yamakawa, M. Aoyama, S. Matsuoka, T. Kase, Y. Akahane, and H. Takuma: Opt. Lett. 23 (1998) 1468.

17) H. Kiriyama, S. Matsuoka, F. Nakano, and K. Yamakawa: Opt. Rev. 7 (2000) 281.

18) S. Matsuoka and K. Yamakawa: Jpn. J. Appl. Phys. 38 (1999) Pt.2, 114.

19) M. V. Ammosov, N. B. Delone, and V. P. Krainov: Sov. Phys. JETP 64 (1986) 924.

20) U. Eichmann, M. Dorr, H. Maeda, W. Becker, and W. Sandner: Phys. Rev. Lett. 84 (2000) 3550.

21) H. Dewa, H. Ahn, H. Harano, M. Kando, K. Kinoshita, S. Kondo, H. Kotaki, K. Nakajima, H. Nakanishi, A. Ogata, H. Sakai, M. Uesaka, T. Ueda, T. Watanabe, and K. Yoshii: Nucl. Inst. Methods in Phys. Research A 410 (1998) 357.

22) T. Hosokai, M. Kando, H. Dewa, H. Kotaki, S. Kondo, H. Hasegawa, K. Horioka, and K. Nakajima: Opt. Lett. 25 (2000) 10.

23）瀬谷 道夫，桑原 輝隆：加速器技術に関する先端動向調査 NISTEP Rpt. No.67 (科学技術庁科学政策研究所, 2000年12月).

24) C. Rose-Petruck, R. Jimenez, T. Guo, A. Cavalleri, C. W. Siders, F. Raksi, J. A. Squier, B. C. Walker, K. R. Wilson, and C. P. J. Barty: Nature 398 (1999) 310.

25) A. B. Borisov, J. Santoro, A. V. Tassle, Y. Dai, K. Boyer, and C. K. Rhodes: $7^{\text {th }}$ Int. Conf. X-ray Lasers (June 18-23, 2000) P53 and P54.

26) M. Wilmanns: J. Synchrotron Rad. 7 (2000) 41.

27) M. Kado, T. Kawachi, N. Hasegawa, M. Tanaka, K. Sukegawa, A. Nagashima, K. Nagashima, A. Sasaki, and Y. Kato: $7^{\text {th }}$ Int. Conf. X-ray Lasers (June 18-23, 2000) O3. 